Open Access to Pharmaceutical and Medical Research
uDDT* s\%

Open 1 Access

Review Article

\title{
Immunomodulators in the Treatment of Psoriasis
}

\author{
Namitha Maniyan*, K. Sreejith, Cherakkulath C. Neena, B. Athulnadh, P.P Muhamed Faris, K.V. Musaina \\ Thasneem, K Gayathri
}

Departement of Pharmacy Practice, College of Pharmaceutical Sciences, Govt. Medical College, Kozhikode, Kerala-673008, India

\begin{abstract}
Psoriasis is a chronic T lymphocyte mediated systemic inflammatory disease characterised by recurrent exacerbations and remission of thickened, erythematous and scaling plaque and multiple comorbidities. Based on morphology and extend of involvement dermatosis may range from innocuous lesion to wide spread life threatening pustular and erythrodermic forms. Psoriasis is a multifactorial skin disease and it involves a complex pathogenesis. It can be explained by a immunological disregulation of cell function along with differentiation or proliferation of keratinocyte. Psoriasis treatment aims to reduce skin inflammation and to clear skin. Conventional therapy usually includes topical, light and systemic medications. All the three therapies are found to be good for the treatment but are associated with a number of side effects like increased skin sensitivity, burning, skin staining, xerosis and alopecia etc. Nowadays various recent therapeutic advances are attempting to control the $\mathrm{T}$ cell expression by the suppression of same and are correlates with the clinical remission. Immunomodulators and biological therapy contribute a new way for psoriasis therapy. These drugs are more safer, effective and selective immunosuppressive agents as compared to conventional agents. This review summarisesthe variousimmunomodulators used in the treatment of psoriasis
\end{abstract}

Keywords: Psoriasis, conventional therapy, immunomodulators

Article Info: Received 02 Sep 2020; $\quad$ Review Completed 16 Oct 2020; $\quad$ Accepted 24 Oct 2020; Available online 15 Nov 2020

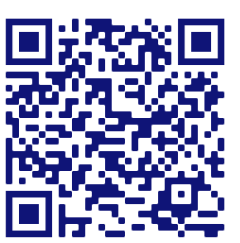

Cite this article as:

Maniyan N, Sreejith K, Neena CC, Athulnadh B, Faris PPM, Thasneem KVM, Gayathri K, Immunomodulators in the Treatment of Psoriasis, Journal of Drug Delivery and Therapeutics. 2020; 10(6):213-215 http://dx.doi.org/10.22270/jddt.v10i6.4530

Namitha Maniyan, Departement of Pharmacy Practice, College of Pharmaceutical Sciences, Govt. Medical College, Kozhikode, Kerala-673008, India

\section{INTRODUCTION}

Psoriasis is a chronic $\mathrm{T}$ lymphocyte mediated systemic inflammatory disease characterised by recurrent exacerbations and remission of thickened, erythematous and scaling plaque and multiple comorbidities. ${ }^{1}$

It affects usually $0.5-1.5 \%$ individual worldwide and are characterised by erethematous scaly plaque involving the scalp and extensors of limb. The affected individual may suffer from physical psychological and social morbidity. Based on morphology and extend of involvement dermatosis may range from innocuous lesion to wide spread life threatening pustular and erythrodermic forms. Palms, soles and genitalia are the common affected sites. ${ }^{2}$

\section{PATHOGENESIS}

Psoriasis is a multifactorial skin disease and it involve a complex pathogenesis. ${ }^{3}$ It can be explained by a immunological disregulation of cell function along with differentiation or proliferation of keratinocyte. ${ }^{4}$
An array of factors which are known to be involved in the disease pathogenesis are antigen presenting cell(APC), T cells, keratocytes, langerhans cells, macrophages, natural killer cells, Th1 type cytokines, growth factors like vascular endothelial growth factors, keratocyte growth factors. ${ }^{3}$ Th1 and Th17 plays a key role in disease pathogenesis. 4

Any unknown antigen causes $\mathrm{T}$ cell activation which leads to the secretion of cytokines. Keratocyte proliferation is responsible for the characteristics psoriatic lesion. ${ }^{3}$ The naive cell get presented with antigen by activated langerhans cell. Recently developed animal models and studies provided new evidence for role of pathogenic lymphocyte in the initiation of disease. ${ }^{5}$

A recently discovered class of posttranscriptional regulators of gene expression called microRNA have critical function in health and disease. ${ }^{6}$ 


\section{CONVENTIONAL THERAPY}

Psoriasis treatment aims to reduce skin inflammation and to clear skin. Conventional therapy usually includes topical, light and systemic medications.

Topical treatment: Mild to moderate psoriasis can be effectively treated using creams and ointments. Topical medications can be combined with oral or light therapy if the disease is more severe in nature. Topical treatment includes use of topical corticosteroids, vitamin D analogue, anthralin, topical retinoid, salicylic acid, coal tar and other moisturizers. Even though these agents are used, are associated with adverse effects like increased sensitivity towards sunlight, skin irritation, and itching or stains skin.7,8

Light therapy (Phototherapy): Use either natural or artificial ultraviolet light. It involves exposure of skin to controlled amount of light. Most common type of light therapy includes ultraviolet A (UVA) and ultraviolet B (UVB), either alone or in combination with medication. Along with this Goerckermantherapy (combination of UVB with coal tar), PUVA therapy are also used. This kind of light therapy are associated with both short term and long term side effects including nausea, headache, burning, itching, dry and wrinkled skin, freckles, increased sun sensitivity and increased risk of skin cancer including melanoma. ${ }^{9}$

Systemic therapy: If a patient suffering from severe psoriasis or he is resistant to any other therapy, systemic therapy is the drug of choice. Systemic therapy critically involves use of injections and oral medication, and it includes retinoids, methotrexate, acitretin and so on.They are teratogenic and should be avoided in pregnancy and other adverse effects include elevated serum lipid, gereralisedxerosis and alopecia. ${ }^{10}$

\section{IMMUNOMODULATORS}

Various recent therapeutic advances are attempting to control the T cell expression by the suppression of same. ${ }^{11}$

TNF $\boldsymbol{\alpha}$ inhibitors: it includes etanercept, infliximab and adalimubab.

1. Etanercept: it is an USFDA approved TNFoinhibitor it is a recombinant DNA made fusion protein. It fuses to the IgG1 antibody. Both macrophages and lymphocyte produces this cytokine called TNFo. Which in turn mediate immune mechanism by attracting WBCs to the site of inflammation that intiate and amplify inflammation. ${ }^{12,13}$

2. Infliximab: A chimeric monoclonal antibody, given as aslow injection to vein in an interval of 6-8 days.Infliximab have high affinity towards $\mathrm{TNF} \alpha$, there by neutralizes the activity by binding to it and to other transmembrane forms. It also have the capacity of lysing cells involved in the inflammatory process. ${ }^{14,15}$

3. Adalimumab: It is a subcutaneous injection generally recommended to non responders. Adalimumab binds to TNF $\alpha$ and inhibit it interaction with p55 and p75 and also lyses the cell which express surface tumor necrosis factor in the presence of a compliment. The benefit of using adalimumab in psoriasis is that it decreases inflammatory skin infiltration and epidermal thickness. In addition it alters the biological responses regulated by TNF. 16

\section{Efalizumab}

A recombinant humanised monoclonal antibody, once in a week dose and given subcutaneously. ${ }^{17}$ Target for efalizumab is CD11a; a lymphocyte function associated antigen 1 and it is an immunosuppressant. It acts by inhibiting activated lymphocyte and the cell migration to the tissue from blood vessels. 18

It may associated with bacterial sepsis, viral meningitis, invasive fungal infections and progressive multifactorial leukoencephalopathy (PML) caused by JC virus infection. 19,20 In a group of 500 patients treated with efalizumab, four reported to have PML.18

\section{Alefacept}

A genetic engineered immunosuppressive drug. It interferes with lymphocyte activation and thud used to control inflammation with plaque formation. Being a fusion protein it combines with a protein of antibody which in turn blocks the $\mathrm{T}$ cell growth and activation.

It act by dual mechanism- one is to inactivate CD4+ and CD8+ $\mathrm{T}$ cell by interfering CD2 on $\mathrm{T}$ cell membrane thus block co stimulatory molecule LFA-3/CD2 interaction. Another is to induce apoptosis of memory effectors $\mathrm{T}$ lymphocyte. $7.5 \mathrm{mg}$ iv or $15 \mathrm{mg}$ iv for 12 week is the usual dose of alefacept.21

\section{Interleukin}

They are the group of cytokine that are first expressed in WBC. Human genome encodes more than $50 \mathrm{IL}$ and related protein. ${ }^{22}$ In the pathogenesis of psoriasis, aberrant type 1 immune response has been linked likeIL-12 and IL-23, so they represent appropriate therapeutic targets. ${ }^{23}$

IL-12 p40 is over expressed in psoriatic plaque. So in order to block IL-12 and IL-23 a fully human IL-12/13 monoclonal antibody (CNT012/3) was developed. It is having high affinity towards P40 subunit of IL-12 neutralizing the bioactivity. 24

\section{Denileukin}

Denileukin Diftitox, fusion protein which target both normal activated and malignant $\mathrm{T}$ cell thus showing antipsoriatic activity. It is an engineered protein combination of IL-2 and diphtheria toxin. It involves killing of cell by introducing the diphtheria toxin into IL binding

\section{$A B X-I L-8$}

Fully human monoclonal antibody that target IL-8. It is widely approved in China

ABX-IL-8 bind to human IL8 with high affinity which make it unable to cross-react to chemokines. It also blocks binding of IL8 to IL8 receptor and inhibit IL8 dependent neutrophil activation migration and degranulation. 25

\section{Apremilast}

It is a phosphodiesterase 4 inhibitor (PDE4); orally administered drug that used in management of both plaque psoriasis and psoriatic arthritis. ${ }^{26}$ PDE4 has role in immune regulation by cAMP degradation. It cause cAMP accumulation that in turn modifies the downstream signalling of pathways of both innate and adaptive immune system. 27

As a result the TNF $\alpha$ and IL-23 decreases and increase in anti-inflammatory mediators like IL-10 occurs. Daily recommended dose is $30 \mathrm{mg} \mathrm{BD}, 10 \mathrm{mg}$ morning dose with daily increment of $10 \mathrm{mg}$ until $6^{\text {th }}$ day then same dose thereafter. ${ }^{28}$ 


\section{CONCLUSION}

Psoriatic patient suffer from physical, social and psychological co-morbidities; and they tend to get abscond from their social activities due to depression and stress. Although there are many different treatment options, they often have major side effects. Immunomodulators and biological therapy contribute a new way for psoriasis therapy. As clinicians and researchers build upon this knowledge in the years to come, we can offer psoriasis patients an increasingly diverse and powerful therapeutic armamentarium.

\section{REFERENCES}

1. Wells BG, SChwinghammer TL, Dipiro JT, Dipiro CT. Pharmacoterapy Handbook. Tenth Edition. Newyork: McGraw-Hill; 2017

2. Lowes MA, Kikuchi T, Fuentes-Duculan J, Cardinale I, Zaba LC, Haider AS, Bowman EP, Krueger JG. Psoriasis vulgaris lesions contain discrete populations of Th1 and Th17 T cells. Journal of Investigative Dermatology. 2008 May 1; 128(5):1207-11.

3. Das RP, Jain AK, Ramesh V. Current concepts in the pathogenesis of psoriasis. Indian journal of dermatology. 2009 Jan; 54(1):7.

4. Ogawa E, Sato Y, Minagawa A, Okuyama R. Pathogenesis of psoriasis and development of treatment. The Journal of dermatology. 2018 Mar; 45(3):264-72.

5. ORTONNE JP. Aetiology and pathogenesis of psoriasis. British Journal of Dermatology. 1996 0ct; 135:1-5.

6. Sonkoly E, Wei T, Janson PC, Sää A, Lundeberg L, TengvallLinder M, Norstedt G, Alenius H, Homey B, Scheynius A, Ståhle M. MicroRNAs: novel regulators involved in the pathogenesis of psoriasis?. PloS one. 2007 Jul 11; 2(7):e610.

7. Ippolito F, Carducci M, Fazio M, Giacalone B, Giannolti B, Carli P, Massone L, Borghi S, Chimenti S, Legge A, Lisi P. Short-and long-term considerations concerning the management of plaque psoriasis with low-dose cyclosporin. Dermatology. 1993; 187:19-29.

8. Rebora A. Conventional therapies for psoriasis. Reumatismo. 2007:77-80.

9. NPF

10. McClure SL, Valentine J, Gordon KB. Comparative tolerability of systemic treatments for plaque-type psoriasis. Drug safety. 2002 Nov 1; 25(13):913-27.

11. Kormeili T, Lowe NJ, Yamauchi PS. Psoriasis: immunopathogenesis and evolving immunomodulators and systemic therapies; US experiences. British Journal of Dermatology. 2004 Jul; 151(1):3-15.

12. Papp KA, Tyring S, Lahfa M, Prinz J, Griffiths CE, Nakanishi AM, Zitnik R, Van De Kerkhof PC, Etanercept Psoriasis Study Group. A global phase III randomized controlled trial of etanercept in psoriasis: safety, efficacy, and effect of dose reduction. British Journal of Dermatology. 2005 Jun; 152(6):1304-12.

13. Romero-Mate A, Garcia-Donoso C, Cordoba-Guijarro S. Efficacy and safety of Etanercept in psoriasis/psoriatic arthritis. American journal of clinical dermatology. 2007 Jun 1; 8(3):143-55.

14. Gottlieb AB. Infliximab for psoriasis. Journal of the American Academy of Dermatology. 2003 Aug 1; 49(2):112-7.

15. Antoni C, Manger B. Infliximab for psoriasis and psoriatic arthritis. Clinical and experimental rheumatology. 2002 Nov 1; 20(6; SUPP/28):S-122.

16. Menter A, Tyring SK, Gordon $\mathrm{K}$, Kimball $\mathrm{AB}$, Leonardi $\mathrm{CL}$, Langley RG, Strober BE, Kaul M, Gu Y, Okun M, Papp K. Adalimumab therapy for moderate to severe psoriasis: a randomized, controlled phase III trial. Journal of the American Academy of Dermatology. 2008 Jan 1; 58(1):106-15.

17. Li S, Wang H, Peng B, Zhang M, Zhang D, Hou S, Guo Y, Ding J. Efalizumab binding to the LFA-1 $\alpha \mathrm{L}$ I domain blocks ICAM-1 binding via steric hindrance. Proceedings of the National Academy of Sciences. 2009 Mar 17; 106(11):4349-54.

18. Hansen ND, Madsen C, Stenager E. Progressive multifocal leucoencephalopathy. The Italian Journal of Neurological Sciences. 1996 Dec 1; 17(6):393-9.

19. Berger JR, Houff SA, Major EO. Monoclonal antibodies and progressive multifocal leukoencephalopathy. InMAbs 2009 Nov 1 (Vol. 1, No. 6, pp. 583-589). Taylor \& Francis.

20. Efalizumab FDA Warning. Retrieved 7 December 2008

21. Scheinfeld N. Therapy-resistant psoriasis treated with alefacept and subsequent narrow band ultraviolet B phototherapy with total clearing of psoriasis. Dermatology online journal. 2005; 11(2).

22. Krueger GG, Langley RG, Leonardi C, Yeilding N, Guzzo C, Wang Y, Dooley LT, Lebwohl M. A human interleukin-12/23 monoclonal antibody for the treatment of psoriasis. New England Journal of Medicine. 2007 Feb 8; 356(6):580-92.

23. Gottlieb AB, Evans R, Li S, Dooley LT, Guzzo CA, Baker D, Bala $M$, Marano CW, Menter A. Infliximab induction therapy for patients with severe plaque-type psoriasis: a randomized, double-blind, placebo-controlled trial. Journal of the American Academy of Dermatology. 2004 Oct 1; 51(4):534-42.

24. SchÖn MP, Detmar M, Parker CM. Murine psoriasis-like disorder induced by naive CD4+ T cells. Nature medicine. $1997 \mathrm{Feb}$; 3(2):183.

25. Wang B, Roskos L, Osborn K, Lu H, Kim M, Pasumarthi R, Raie $\mathrm{N}$, Tabrizi M. A population pharmacokinetic (PK) analysis of ABX-IL8, a fully human monoclononal IGG2 antibody, in psoriasis patients. Clinical Pharmacology \& Therapeutics. 2005 Feb; 77(2):P91.

26. Afra TP, Razmi TM, Dogra S. Apremilast in psoriasis and beyond: Big hopes on a small molecule. Indian dermatology online journal. 2019 Jan; 10(1):1.

27. Kushwaha AS, Repka MA, Murthy SN. A novel apremilast nail lacquer formulation for the treatment of nail psoriasis. AAPS PharmSciTech. 2017 Nov 1; 18(8):2949-56. 